\title{
Analysis on the Comparative advantages of Innovation and Entrepreneurship Education in Universities across the Taiwan Straits
}

\author{
Yanfang Zhang ${ }^{1, a}$, Qingyun Xia ${ }^{2, b}$ \\ 1,2Straits Institute of Minjiang University, Fuzhou, Fujian, China \\ ${ }_{1,2}$ Institute of Higher Education Cooperation and Exchange across the Taiwan Strait, Minjiang \\ University, Fuzhou, Fujian, China \\ aE-mail: yanfang825@163.com \\ bE-mail: 13503040010@139.com
}

Keywords: Innovation and entrepreneurship education, Comparative advantages, Universities across the Taiwan Straits

\begin{abstract}
Since 2015, innovation and entrepreneurship education in universities has developed rapidly under the promotion of national policies in mainland China. Innovation and entrepreneurship courses have been gradually popularized, the education has developed in a diversified way, the construction of innovation and entrepreneurship practice platform has been accelerated, various innovation and entrepreneurship competitions have been launched, and to start their own business has increasingly become the employment choice for college students. The innovation and entrepreneurship education in universities of Taiwan started early with high degree of resource integration, relatively complete curriculum system, distinctive characteristics, strong faculty, and a better ecological environment. Universities on both sides of the Taiwan Straits have their own advantages in innovation and entrepreneurship education, and there is a vast space for cooperation. By analyzing the comparative advantages of innovation and entrepreneurship education in universities across the Straits, this paper explores the prospects of cooperation with a view to achieving win-win development across the Straits.
\end{abstract}

\author{
海峡两岸高校创新创业教育比较优势分析 \\ 张妍芳1, a , 夏青云 2 ,b \\ 1,2闽江学院海峡学院, 福州, 福建, 中国 \\ 1,2 闽江学院海峡两岸高等教育合作与交流研究所, 福州, 福建, 中国 \\ aE-mail: yanfang825@163.com \\ bE-mail: 13503040010@139.com
}

关键词：海峡两岸高校，创新创业教育，比较优势

中文摘要: 自 2015 年以来, 大陆高校创新创业教育在国家政策的推动下快速发展。创新创业 课程逐渐普及, 双创教育多元化发展, 创新创业实践平台建设加速, 各项创新创业赛事火热 开展, 创业日益成为越来越多大学生的就业选择。台湾高校的创新创业教育起步早, 资源整 合度高, 课程体系较为完善, 创新创业教育特色鲜明, 师资力量强, 创新创业教育生态较好。 两岸高校在创新创业教育方面各具优势, 存在着广阔的合作空间。本研究通过分析两岸高校 创新创业教育的比较优势, 展望两岸高校创新创业教育的合作前景, 以期能够实现两岸的共 赢发展。 


\section{1. 研究背景与意义}

\section{1 研究背景}

长久以来, 中国一直位处在世界经济产业链条和价值链条的最底端, 长期扮演世界工厂“打 工者”的角色。中国经济摆脱低水平发展状态的关键是彻底转变经济发展方式, 通过创新引领 发展。另一方面, 中国人口多, 就业任务重。但随着人口红利减少、经济结构转型升级, 经 济增长对拉动就业的作用越来越有限。在这种形势下, 更要通过创业带动就业, 实现经济发 展和扩大就业的可持续发展。由此，“大众创业，万众创新”顺势而生。2015 年，李克强总理 在政府工作报告中将“大众创业、万众创新”上升到国家经济发展新引擎的战略高度。随后， 国家又相继出台了《关于深化体制机制改革加快实施创新驱动发展战略的若干意见》、《关于 大力推进大众创业、万众创新若干政策措施的意见》等一系列指导文件, 各级地方政府也出 台了多方面的鼓励政策，中国社会掀起了一股创新创业的热潮。

\section{2 研究意义}

大学生是最富创造活力和潜力的群体，因此要打造“大众创业，万众创新”这一国家经济

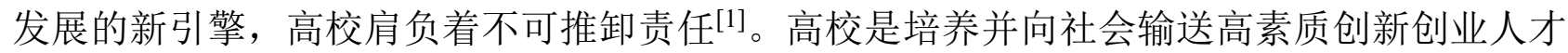
的重要阵地。只有通过高校良好的创新创业教育和高水平的创新科研,将高质量的创新资源输

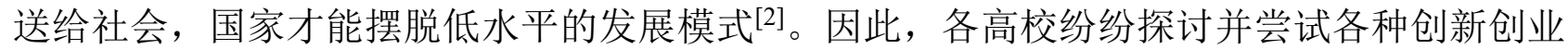
人才培养模式, 各类研究高校创新创业教育的文章也层出不穷。

中国知网的数据显示，学术界关于创新创业教育的研究早在 1999 年就开始，这期间各类 关于创新创业教育的学术论文有 27300 余篇, 其中关于高校创新创业教育研究的文献有 5900 余篇, 而 2015 年以来发表的关于高校创新创业教育研究的文献有 5100 余篇, 占到该方面研 究的 $86 \%$ 以上。然而纵观这些研究高校创新创业教育的文献, 研究台湾高校创新创业教育或 海峡两岸高校创新创业教育比较研究的文献仅 30 余篇。在这 30 多篇的研究台湾高校创新创 业教育的文献中, 又多是研究台湾高校创新创业教育的经验对大陆高校的借鉴意义, 是单方 面的学习和借鉴, 鲜有文献站在海峡两岸高校创新创业教育各自优势的角度去探讨海峡两岸 高校在创新创业教育方面的合作前景。

本研究从分析海峡两岸高校在创新创业教育方面各自的比较优势出发, 展望两岸高校互 利共赢的创新创业教育合作前景, 为高校创新创业教育研究提供一个新的思考角度。也希望 在丰富我国高校创新创业教育的理论研究的同时, 为两岸高校创新创业教育合作的实践提供 参考。

\section{2. 海峡两岸高校创新创业教育比较优势}

如上文所述，自 2015 年政府工作报告中将“大众创业、万众创新”上升为国家战略以来， 各类研究高校创新创业教育的文章呈现井喷状态。但大多数文献是研究大陆高校在创新创业 教育方面存在的不足及改进措施,而对大陆高校在创新创业教育方面存在的优势研究不足。不 可否认，大陆高校在创新创业教育方面起步较晚，也存在不少问题。但随着近几年政府出台 的各项创新创业鼓励政策的大力推动下, 大陆各高校在创新创业教育上也取得了长足的进步。 因此，在探讨两岸高校创新创业教育合作前景时，除了认识到自身的不足，更应挖掘各自的 优势, 互相取长补短。这样基于平等、互利、共赢基础上的合作才更加长久, 前景才更加广 阔。

\section{1大陆高校创新创业教育的比较优势}

2.1.1 大陆高校深化课程体系改革，普遍开设创新创业课程，双创教育方式多元化发展。

随着国家政策的大力推动, 大陆各高校进行课程体系改革, 纷纷开设了创新创业相关课 程, 以培养学生的创新创业意识和能力。例如, 清华大学重点建设“跨学科系统集成设计挑战” 
等系列挑战性示范课; 北京大学开设“北大十五堂创业课”等实战课程 ${ }^{[3]}$; 厦门大学开设了《大 学生创业计划与实践》及《大学生 K A B 创业基础》等课程; 福州大学开设了《创业学》、《创 业管理》和《创业设计实践》等必修和选修课。西南大学构建“ $1+X$ ”创新创业教育课程体系, 即 1 门“创新创业教育基础”必修课+30 门以上创新创业教育选修课和 4 门创新创业行业培训 课, 为学生提供丰富的学习资源。

除了开设双创课程，各高校还积极探索多种创新创业育人模式。例如，温州大学的“3+1” 创新人才培养模式改革, 将把分散在各院系、有创业意愿且已完成本科 3 年学习的学生, 集 中选拔到创业学院进行一年的针对性培养 ${ }^{[3]}$ 。闽江学院将第一课堂、第二课堂的相互融合, 并纳入学分管理。此外, 各高校还积极推出一批慕课、微课和视频公开课等在线开放课程, 形成了多维度立体的创新创业教育模式。

2.1.2 大陆高校各类创新创业实践平台建设加速, 创业孵化器、育成中心等实践基地日益普及。

培养大学生的创新创业能力不仅要依靠课堂知识的传授, 更应该通过创新创业实践, 提 高大学生的创新创业能力和水平。不少高校专门成立创新创业学院或创新创业中心, 统筹学 校的各项创新创业教育工作, 也加速了高校创新创业实践平台的建设。例如, 华北电力大学 成立创业服务中心，设了6个专业的创业孵化室，为学生提供公司注册、企业管理、创业孵化、 融资对接等“一站式”创业指导与服务 ${ }^{[3]}$ 。福州大学的国家大学科技园以创新和科技成果转化、 高新技术企业孵化、创业型人才培养及集聚为主要功能, 推动创业实践。浙江大学打造“智能 制造国家专业化众创空间”、“浙江大学e-WORKS创业实验室”等众创空间，强化科技创新实 践训练和创新创业教育, 助力培养创新创业人才。

\subsection{3 以赛促创，进一步推动高校创新创业教育改革。}

为加快培养创新创业人才, 推动高校开展创新创业教育的综合改革, 由教育部、共青团 中央等多单位共同举办的“互联网+'大学生创新创业大赛”、“挑战杯”大学生课外学术科技作 品竞赛”、“创青春” 全国大学生创业大赛三大创新创业赛事，以及诸如大学生“创新、创意、 创业”电子商务挑战赛、“全国大学生创业设计暨沙盘模拟经营大赛”等各类创新创业学科竞 赛, 在全国如火如茶地展开。随着这些赛事常态化开展, 为各高校创新创业教育成果提供了 展示的平台, 也为大学生优秀创业项目进行了广泛的宣传, 并提供社会资源对接的机会, 这 些都有效地激发了大学生创新创业的热情, 推动各高校创新创业教育的改革。例如, 2018年 的第四届“互联网+”大学生创新创业大赛共有 2200 多所高校的 265 万大学生报名参赛, 规模空 前 $^{[4]}$ 。各高校为挖掘和培育参赛项目, 投入大量的人力物力财力, 开展创新创业课程体系、 教学方法和管理制度等方面的综合改革, 培养学生的创新精神、创业意识和创新创业能力。 2.1 .4 大学生就业观念改变, 创业成为越来越多大学生的就业选择。

国家政策的大力推动, 各高校创新创业教育的全面普及, 各项创新创业赛事的广泛宣传, 为大学生创新创业营造了良好的社会氛围, 促使大学生就业观念的改变。过去, 许多大学生 和家长都认为大学毕业后考公务员, 或在大国企、事业单位工作才体面, 导致了大学生对创 新创业缺乏热情。但是随着大学教育从“精英教育”向“大众教育”转变, 并且随着各高校全面 推广创新创业教育, 大学生逐渐认识到创新创业能力是大学生应该具备的有助于未来长远发 展的关键能力。同时, 国家优惠政策的扶持, 学校专业辅导的推动, 社会资源的对接, 也为 大学生创业提供了有力的支持。中国大学毕业生创业率已达 $3 \%$, 超过发达国家 $1.6 \%$ 水平近一 倍 ${ }^{[5]}$ 。

\section{2 台湾地区高校创新创业教育优势}

台湾的“三创”，即创新、创意、创业，比大陆的创新创业多了一个创意，但其内涵基本 是一样的。台湾高校的“三创”教育起步较早，相对于大陆高校的双创教育主要优势体现在以 下四点。

2.2.1 台湾高校创新创业教育资源整合度高, 课程体系较为完善。

创新创业能力是一种综合能力, 要培养学生的创新创业能力, 学生不但要掌握本专业的 
知识, 还需要掌握创新创业所需的多学科知识, 例如战略规划、市场营销、人力资源管理、 财务管理、法律、人际交往等诸多方面的综合知识, 才能形成较为完备的知识体系。因此创 新创业教育是一项全面的综合素质的教育, 仅靠独立的一两门创新创业课程的教学, 无法提 升学生的创新创业能力。台湾高校的创新创业教育采用“学程制”的教育模式, 整合了不同院 系专业的教学资源, 满足创新创业教育的综合性要求。台湾高校“学程制”的创新创业课程体 系一般规定学生需修满 15-26 不等的创新创业课程学分。例如, 台湾最早开始创新创业教育 的中山大学的“创业管理学程”开设了 6 门 18 学分的核心课程和 28 门 84 学分的选修课程供学 生选择修读。有些台湾高校的创新创业课程不但整合本校不同系院间的资源, 还创造性地整 合了不同学校间的优势资源。例如。高雄海洋科技大学、台南科技大学和高苑科技大学于 2008 年合作推出跨校性的“创意与创业学程”, 整合三校各自的专长领域, 采取学分互认, 致力于 培养具有创意思考能力的创业人才 ${ }^{[6]}$ 。这些 “学程制”的创新创业课程打破了院系乃至学校间 的专业壁垒, 课程的融合度更高, 内容涵盖创业过程的各个环节, 更有助于提升学生的综合素 质, 培养学生创业所需的综合能力。

2.2.2 台湾高校的创新创业教育服务地方经济, 注重文化创意和个性化发展, 特色鲜明。

台湾高校很注重创新创业教育的个性化与特色，他们往往结合本校优势和所在社区及当 地产业的资源, 开展各具特色的创新创业教育活动。例如, 中兴大学创新创业教育围绕茶产 业、茶乡社区进行; 高雄医学大学创新创业教育旨在培养智慧健康照护人才; 台湾海洋大学 的创新创业教育则重点服务当地渔村。

台湾有着“小而美”的优势, 其文化创意享誉世界。文化创意产业成为台湾大学生就业的 重要途径之一, 这也得益于台湾高校的创意、创新和创业教育, 使台湾高校成为激发创意、 创新与创业精神的主要源头。台湾辅仁大学的“创意创新创业学程”就专门开设凸显“文化创 意”特色的选修课程, 要求学生必须修读 6 学分的文化创意选修课。

2.2.3 台湾高校重视创新创业师资队伍建设, 师资力量强。

台湾高校重视创新创业师资队伍的建设, 采取多种措施来培养创新创业教育师资。包括成 立教师成长工作坊, 通过理论专题讲座、观摩活动、讨论交流或实务操作等多种组织方式, 共同探讨有关创意创新创业教育的话题, 以提升教师的创新创业教育能力; 建设教师专业成 长( 学习) 社群, 分享教学经验, 促进教师的自我学习成长; 组建创意教育指导种子团队与 推进机构, 帮助教师掌握开展创新创业教学的相关理论, 提升教学技能技巧; 开设促进教师 创新创业教学水平提升的继续教育, 增进教学效能, 等等 ${ }^{[7]}$ 。

除了培养校内创新创业教育师资力量, 台湾高校还聘请企业高管、业界资深专家，优秀 校友等来校授课或开设讲座, 为学生进行答疑解惑和创业辅导, 使学生对创新创业的认知更 贴合实际，有效提高学生的创新创业技能。

2.2.4 台湾高校的创新创业教育与企业合作密切, 创新创业教育生态较好。

台湾高校在创新创业教育方面与企业的联系更为密切, 企业对高校创新创业教育的参与 度也较高。台湾高校通过成立“育成中心”将创新创业教育“推出去”, 主动将创新创业教育延 伸到民间机构、政府部门, 再将企业、政府需求“引进来”, 实现了内外的有效互动和顺畅对 接, 充分整合了学校资源和社会资源, 形成了“高校、企业、社区” 联通的资源网络体系, 突 出了创新创业教育的开放性、实践性与应用性特点, 形成了良好的教育生态。

\section{3. 两岸高校创新创业教育合作前景展望}

两岸高校在创新创业教育方面各具优势，存在着广阔的合作空间。例如，在打造具有校 本特色的双创课程上, 大陆高校可以借鉴台湾高校的经验、做法, 邀请台湾高校参与其双创 课程的开发设计和课程体系的建设, 也可结合当地经济发展的需要, 将一些创新创业课程外 包给台湾高校开设, 以引进台湾具有特色的双创课程。两岸高校还可通过师资互聘、互相开 放创新创业网络精品课程, 以及通过生源流动、学分学历互认等合作, 跨区域整合资源, 实 
现创新创业教育资源的有效利用。台湾高校可以借助大陆高校的创新创业孵化基地, 为台湾 学生的创业项目寻求更多的资金支持和进入更为广阔市场的途径。两岸高校还可组建创业项 目联合团队, 参加各项创新创业大赛, 为优秀的创业项目寻求更多的发展机会, 等等。两岸 高校在创新创业教育领域的合作，不仅有助于实现资源共享，优势互补，促进两岸高等教育 结构调整创新, 还能够为大学生创业提供有力支持, 促进大学生就业, 实现两岸的共赢发展。

\section{致谢}

本文为福建省教育科学“十二五”规划 2015 年度海峡两岸职业教育专项研究课题 A 类一般 项目《闽台联合培养本科人才项目效果研究》(FJJKHX15-026)的阶段性成果之一。

\section{References}

[1] Yaorong Zhang, Jointly Promote the Development of Innovation and Entrepreneurship Education- Report on the Eleventh Cross-Strait (Guangdong and Taiwan) Higher Education Forum, Higher Education Exploration, vol.4, pp. 124-128, 2017.

[2] Leping Zhang, Yuexiong Huang, The Structure and Strategies for Innovation in Science and Technology in Research-oriented Universities, Science \& Technology Progress and Policy, vol.5, pp. 151-153, 2006.

[3] Jin Ke, Chinese Sample of Innovation and Entrepreneurship Education Practice: A Summary of Innovation and Entrepreneurship Education Reform since the 18th National Congress of the Communist Party of China, China Education Daily, Sep. 16th,2017, from http://www.jyb.cn/zgjyb/201709/t20170916_771417.html.

[4] Jiyuan Lin, The 4th China College Student' 'Internet Plus' Innovation and Entrepreneurship Competition was Successfully Completed in Xiamen University, Oct. 16th,2018, from https://cxcy.xmu.edu.cn/info/1001/1301.htm.

[5] Hui Deng, Competition for China's "most innovative brain", Guangming Daily, Oct. 12th,2018, from http://news.gmw.cn/2018-10/12/content_31659982.htm.

[6] Meimao Lin, Practical Experience and Enlightenment of Innovation and Entrepreneurship Education in Colleges and Universities of Taiwan, Fujian Tribune (The Humanities \& Social Sciences Monthly), vol.10, pp. 155-161, 2015.

[7] Qingshou Zhang, Implementing Experiences and Reference Point for the Innovative and Enterprising Education in Taiwan Colleges and Universities, Journal of Minjiang University, vol.158, pp. 109-116, 2016. 